of the former emperor Boris II was ineligible, since he had been castrated") (s. 47). Wystarczy stwierdzić, że Roman miał zostać eunuchem, według niepewnych zresztą, źródeł jeszcze w latach sześćdziesiątych, to dlaczego Samuel miałby czekać ze swoją koronacją akurat do 997 r.? Szerzej na temat wyniesienia Romana do godnosci cara Bułgarii pisał Stanisław Rek (Geneza tytułu carskiego w państwie zachodniobułgarskim, „Balcanica Posnaniensia”, II, 1985, s. 51-57).

Nie wydaje się właściwe określanie Tedora-Piotra, jak również Asena mianem Vlach ruler (s. 199) czy ruler of the Vlach (s. 202). Rumuński uczony jakby zapomniał, że bez względu na to jakie było etniczne pochodzenie braci Asenów, co do którego nie ma pełnej jasności, to stanęli oni po zwycięskim powstaniu przeciw Bizancjum na czele państwa bułgarskiego i byli bułgarskimi władcami. Dziwi (choć może w kontekście głoszonych poglądów nie aż tak bardzo), że w swoich rozważaniach dotyczących pochodzenia Asenów (s. 159-162) pominął fundamentalną, jak się wydaje, pracę Iwana Bożiłowa Familijata na Asenevci (1186-1460) genealogija i prosopografija (Sofija 1994).

Powyższe drobne uwagi nie wpływają na wysoką ocenę monografii Aleksandru Madgearu, która stanowi interesującą próbę ukazania bizantyńskiej obecności militarnej nad dolnym Dunajem w VII - XII, ze szczególnym uwzględnieniem wzmiankowanego w tytule, okresu X-XII w. Z pewnością odegra ona inspirującą do dalszej naukowej dyskusji rolę. Nie bez znaczenia jest i to, że pozwala ona zapoznać się $\mathrm{z}$ ustaleniami nauki rumuńskiej - $\mathrm{w}$ interesujących autora kwestiach - które nie zawsze trafiają do międzynarodowego obiegu naukowego.

Błażej Cecota, Mirosław J. Leszka

\title{
Marta Chaszczewicz-Rydel, Obrazy Batkanów. Mity, stereotypy, nowa imagologia, Oficyna Wydawnicza ATUT, Wroclaw 2013, ss. 339.
}

Wśród prac naukowych wydawanych w Polsce, a poświęconych różnorodnym zagadnieniom związanym z Półwyspem Bałkańskim i wybranym obszarom tej przestrzeni w ciągu ostatnich kilku lat ${ }^{13}$, niepostrzeżenie przemknęło studium Marty

13 Wymieniam kilka tylko tytułów, by wskazać jak wielka jest różnorodność podejmowanej problematyki związanej Bałkanami: K. Jurczak, Dylematy zmiany. Pisarze rumuńscy XIX wieku wobec ideologii zachowawczej, Wyd. UJ, Kraków 2011, ss. 243; D. Wybranowski, Miedzy niepodległością a dezintegracją. Bośnia i Hercegowina w XX i XXI wieku, Wyd. Volumina, Szczecin 2011; J. Rubacha, Butgaria na przełomie XIX i XX wieku. Bułgarskie metamorfozy w publikacjach ,,Świata Stowiańskiego” (1905-1914), Wyd. Uniwersytetu Warmińsko-Mazurskiego, Olsztyn 2012, ss.575; J. Muś, Bośnia i Hercegowina. Etnopolityczne podziaty i ich uwarunkowania, Wyd. KUL, Lublin 2013, ss. 174; Misja butgarska zmartwychwstańców: 150 lat w stużbie Kościołowi i społeczeństwu, red. W. Misztal, W. Mleczko, Wyd. Naukowe Uniwersytetu JP II, Kraków 2013, ss. 186; Bałkany Zachodnie między przeszłością a przyszłościa, red. P. Chmielewski, S. L. Szczesio, Wyd. UŁ, Łódź 2013, ss. 596; M. Kawka, P. Płaneta, Dyskursy 
Chaszczewicz-Rydel, Obrazy Batkanów. Mity, stereotypy, nowa imagologia. Slawistka z Uniwersytetu Wrocławskiego zaprezentowała pracę niezwykle wartościową, która zainteresować może nie tylko bałkanistów. Bałkany, które stały się przedmiotem prezentowanej monografii, nie są bowiem jedynym obszarem, wokół którego narosło szereg stygmatyzujących uproszczeń.

Autorka w oparciu o solidną bazę materiałową podjęła udaną próbę prezentacji mechanizmów stereotypizacji Bałkanów, choć określony w tytule jej rozprawy region faktycznie ograniczyła do wizji obszaru byłej Jugosławii. Uzasadniła to jednak twierdzeniem, iż w postrzeganiu Europy Zachodniej na etapie wojny lat 90 . Bałkany stały się stylistycznym obrazem tego wielokulturowego i wielonarodowego państwa. Samo pojęcie „Bałkany” potraktowała w kategoriach geografii kulturowej wpisanej w literaturę, poddając analizie teksty zróżnicowane pod względem ich literackości (reportaż, powieść) z okresu prawie dwóch dekad (1991-2010). Zewnętrzna perspektywa oglądu tej przestrzeni pozwoliła jej badać konkretne teksty w kontekście bałkańskiej sytuacji społeczno-kulturowej. W tym celu dokonała analizy sposobu rozumienia bałkanizmu z jego opresyjnością, zanurzeniem w stereotypy przy dyskursywnej przemocy konceptualizowania Bałkanów. Materiał, jakim posłużyła się Marta Chaszczewicz-Rydel umożliwił jej spojrzenie na pełne spektrum dyskursów dotyczących nacechowanej pejoratywnie przestrzeni bałkańskiej z ich obrazami funkcjonującymi w szerokim obiegu czytelniczym. W czterech rozdziałach swej monografii: Imagologia w komparatystyce; Od reprezentacji do mitu; Batkany oraz Bałkany w literaturze polskiej, ukazała, na jakie sposoby ujmowano Bałkany w piśmiennictwie i jaki ich obraz stał się obrazem dominującym, a także na ile jego kreacja stała się odpowiedzią na zapotrzebowanie, potwierdzenie przypuszczeń, czy poparcie koncepcji politycznych.

Dla zrozumienia tych procesów dokonała przeglądu i analizy najważniejszych prac poświęconych tej części Europy. Przypomniała więc rolę sztandarowego dzieła Jovana Cvijicia, La Péninsule Balkanique: Géographie Humaine, poddała analizie linię etnopsychologiczną mieszkańca Bałkanów wypracowaną w badaniach Petara Džadžicia, odwołała się do rudymentarnych prac poświęconych tej przestrzeni, a wśród nich m.in. do dzieła Marii Todorowej, Bałkany wyobrażone, do studium Božidara Jezernika, Dzika Europa. Bałkany w oczach zachodnich podróżników, do teorii Milicy Bakić-Hayden, uwzględniając także literacki obraz stworzony przez Agatę Christie.

Kreśląc wizję Bałkanów i dyskursu wokół nich na bazie prac autorów anglosaskich, postawiła szereg pytań, dotyczących trwałości i aktualności obciążonego stereotypami oglądu tej przestrzeni w kontekście kulturowego zderzenia pojęcia Europy z Bałkanami. Wskazała przy tym na sposoby postrzegania Europy wobec nacecho-

o Macedonii, Wyd. UJ, Kraków 2013, ss. 314; K. Stępnik, Macedonia w prasie polskiej (1903-1914), Wyd. UMCS, Lublin 2014, ss. 285; I. Stawowy-Kawka, Albańczycy w Macedonii 1944-2001, Wyd. UJ, Kraków 2014, ss. 406; I Wojna Światowa na Bałkanach. Działania militarne i polityczne w latach 1914-1918 , red. A. Krzak, Szczecin 2014, ss. 405; A. Kurpiel, Cztery nazwiska, dwa imiona. Macedońscy uchodźcy wojenni na Dolnym Śląsku, Nauka i Innowacje, 2015. 
wanej pejoratywnie percepcji mieszkańców Półwyspu. Relacje z Bałkanów powielają bowiem stereotyp barbarzyńskości regionu (Robert D. Kaplan), co dowodzić może, zgodnie z twierdzeniem Vesny Goldsworthy, ,mentalnościowej i symbolicznej kolonizacji Bałkanów" przez autorów anglosaskich (s. 110). Badaczka zwróciła też uwagę, iż na takim postrzeganiu zaważyła w dużym stopniu realizacja celów politycznych. Dowiodła, że zapisane narracje o tym regionie w historii zachodnioeuropejskiej wskazują, iż Bałkany przyjmują postać wszystkiego, przed czym Europa próbuje się bronić, przyczyniając się do ich wykluczania oraz reprodukowania stereotypowej syntagmy. Liczne definicje tej przestrzeni, jakie zaprezentowała, powielają zaś zbiorowy, euroatlantycki i stereotypowy sposób postrzegania Bałkanów powiązany z tzw. „misją cywilizacyjną Europy Zachodniej wobec Orientu” (s. 84-86).

Przyjęta przez Autorkę perspektywa imagologii komparatystycznej, uwzględniająca złożone wzajemne relacje pomiędzy mniejszymi narodami pozwoliła jej wyjaśnić sposoby przedstawiania poszczególnych krajów w ich tekstach własnych, spełniając reprodukcyjną rolę w ugruntowaniu określonych zwyczajów i sposobów postrzegania, ale także kreowania nowych wzorów. Prowadzone przez nią poszukiwania obrazu w sferze języka, wraz z istotnym kontekstem pozaliterackim, umożliwiły jej ukazanie gry perspektyw, stereotypizację innego a także przenoszenia stereotypów na ideologie. Co istotne, w odtwarzaniu tego obrazu Autorka nie pominęła prac badaczy wywodzących się z Bałkanów i ich antropocentrycznego spojrzenia na własny region. Zauważyła, iż prowadzone tam badania mają pewien pierwiastek wspólny, łączący Bałkańczyków - stanowi go przeciwstawienie się wobec zachodnioeuropejskiego poczucia wyższości w stosunku do Bałkanów, co ma służyć potwierdzaniu indywidualnego dorobku i wytworzeniu zbioru wartości sprzyjających rozwojowi współpracy oraz przenikaniu heterostereotypów. Przypomniała, iż w okresach wcześniejszych istniały instytucje, które podejmowały badania związków kulturowych Bałkanów z Europą (Bałkański Instytut, 1934-1941). Prześledziła więc wcześniejsze inicjatywy w działalności Petara Skoka, Ratka Parežanina, zwracając uwagę na istnienie 2 nurtów w poglądach dotyczących Bałkanów. Jak skonstatowała, w okresie międzywojennym zaznaczała się pozytywna ocena Turcji i zauważalny był pewien kompleks Europy wobec tej przestrzeni. Nie bez znaczenia pozostał także zespół wyobrażeń podkreślających negatywne konsekwencje położenia geograficznego, a także tendencje dowodzące, iż cywilizacja na Bałkanach rozpatrywana z własnej perspektywy jest swoistą ,wspólnotą w różnicach”.

W dyskurs bałkanistyczny wpisuje się również literatura, z najwymowniejszym przykładem przeniesienia obrazu wielokulturowości odnajdywanym w pisarstwie Ivo Andricia. Także twórczość prac autorów współczesnych z Bałkanów prezentuje wizję walki międzycywilizacyjnej obszaru odrzuconego przez Europę, w których twórcy odsłaniają siatkę stereotypów dotyczących zamieszkiwanej przestrzeni, dokumentując tym samym, iż dla nich europejska wiedza o ich ziemiach stanowi głównie powielanie istniejących, wcześniejszych opisów. Podobnie jak dowcipy, w których przedstawia się sąsiednie narody, odnosi się do bałkańskiego systemu wartości, 
jaki nigdzie nie istniał i nie istnieje, choć wbudowuje się w ogląd dominujący w Unii Europejskiej.

Przy analizie utworów polskich autorów, którzy przyjęli Bałkany za tematy swych książek, badaczka nie pominęła reportażu spełniającego istotną rolę w komunikacji społecznej. Dokonana przez nią analiza tekstów o rozpadającej się Jugosławii, wykazała stopniową homogenizację relacji wojennych i rozpętanie swoistej wojny informacyjnej wokół Bałkanów, gdyż na tym właśnie etapie stały się one stylistycznym obrazem Jugosławii, na który nakładało się stereotypowe postrzeganie sąsiednich narodów wobec siebie. Wypowiedzi dziennikarzy, wykazały bowiem kwestię stronniczości piszących (D. Warszawski, piszący o dziczy bałkańskiej, s. 153-159), czy uzależnienia od reprezentowanej przez nich i ich redakcje opcji politycznej, a także powielanie przez nich stereotypów funkcjonujących w Europie Zachodniej. Media odegrały więc swą rolę w kreowaniu nastrojów i wizji o regionie narzucając stronniczość i kreując antyserbskość. W tym kontekście za idealny przykład odzwierciedlający takie narracje i ich różnorodność przyjęła Serbię, gdyż z publikacji reportażystów wyłonił się nacechowany negatywnie obraz Serba. Dowiodła tego również książka Wojciecha Tochmana, Jakbyś kamień jadła. Przytaczane przez niego wypowiedzi muzułmanek kształtowały czarno-biały obraz Serba jako zła, a twierdzenie tego autora, ,że zbrodniarzem może być każdy Serb” (s. 168), wzmacniało jedynie stereotyp bałkański, wskazując, jaka przepaść dzieli Bałkany od Europy.

Jak dostrzegła badaczka, Bałkany stały się swoistym schematem koncepcyjnym także na kartach polskich powieści, których akcję tam właśnie osadzono. Dokonaną analizę tekstów poprzedziła ukazaniem różnych opinii o twórczości danego pisarza. W taki sposób zaprezentowała prozęArtura Górskiego, którego twórczość epatuje sensacją, a jego poszczególne powieści dają obraz Bałkanów z szerokim repertuarem rozpowszechnionych stereotypów. Ukazała skontrastowanie Bałkanów z Europą, jakiego dokonał Górski, kreśląc europocentryczną opozycję pomiędzy odmiennościami kulturowymi i takież wartościowanie, kreując na nowo obraz Serba jako oprawcy (s. 177), namnażając stereotypy Bałkanów oraz „Europejczyka”. Szczególnie rozbudowany zespół cech negatywnych przypisywany potencjalnemu Serbowi, sprawił, że jego etniczna kategoria uległa całkowitej satanizacji - Serb stał się postrachem i przyczyną lęków, wcieleniem bohatera literatury grozy, tzw. „nieumarłego”, wampira. Także literatura fantasy reprezentowana przez powieść Andrzeja Pilipuka, Kuzynki, przywraca nacechowany ujemnie obraz Bałkanów, gdzie nawet czas płynie wolniej, a mord jest cechą typową dla ich mieszkańców. Skontrastowanie tego regionu z Europą prowadzi bowiem do wyeksponowania niegdysiejszości terytorium, zacofania, a elementy prezentowane jako miła, ekologiczna egzotyka, rustykalność albo prymitywizm powinny / mogą budzić obawy, gdyż inaczej niż w Europie, na Bałkanach należy kierować się instynktem i posiłkować intuicją. Autorka dostrzegła, iż w prozie Pilipiuka szczególnie niekorzystne odnośniki dotyczą jednak Albańczyków z Kosowa, utożsamionych z dzikością, prymitywną gawiedzią, zaślepieniem, zabobonem, czy skłonnościami do zlinczowania dziecka. Wykreowany w tym kontekście obraz Bizancjum 
osadzony na historiach o zdradzie, intrygach i zbrodni uczynił z Bałkanów egzotyczny dodatek do Europy.

Za sztandarowy przykład tworzenia i powielania stereotypów o regionie M. Chaszczewicz-Rydel przyjęła prozę Andrzeja Stasiuka, zauważając, że na temat Bałkanów próbowało wypowiadać się wielu autorów, (wśród nich także S. Chwin, konstatujący, iż Bałkany to „okropne kraje”, s. 217). Jednak ten właśnie autor, jeden z najczęściej tłumaczonych na języki obce pisarzy współczesnych-w powielaniu stereotypowej wizji Bałkanów zajął miejsce szczególne. Analizę jego twórczości badaczka poprzedziła próbą przypisania gatunku uprawianej przez niego prozy, zauważając, że zamazane są jej granice genologiczne, co prowadzi do rozmycia prawdy o opisywanym terytorium. Poszukiwanie odpowiedzi na pytanie, czy tworzy on literaturę faktu, czy beletrystykę, przyniosło konstatację o wpływie różnych gatunków na jego pisarstwo. Zaowocowało to eseizacją i tworzeniem literatury tendencyjnej, która reprodukuje stereotyp Bałkanów jako „gorszej Europy”, „nie(do)rozwiniętej, chaotycznej i barbarzyńskiej" (s. 230). Autor bowiem nie starał się sprostać zasadzie obiektywnego relacjonowania swoich podróży (Jadac do Badadag), a już samo bycie „tam” miałoby nadawać jego prozie pozory kompetencji o opisywanej przestrzeni. Jak stwierdziła, Stasiuk kreuje się w swej relacji na pierwszego obcego, który odkrywa Bałkany - jest i odkrywcą, i kolonizatorem. Powiela przy tym stygmatyzujący obraz Serbów, którzy w odbiorze pisarza stali się nosicielami cech opozycyjnych względem idei porządku - utożsamiani z imperializmem, agresją i ekspansją terytorialną. W opozycji do nich Stasiuk prezentuje Albanię, którą darzy sympatią i sentymentem, jako krainę osobliwości, absolutnie dziką i egzotyczną, ale opisywaną z wyrozumiałością jako przestrzeń baśniowa i upoetyzowana. Badaczka, zauważając błędy merytoryczne pisarza (m.in. przypisanie arumuńskiemu miastu Voskopoje założenie pierwszej na Bałkanach drukarni, która faktycznie powstała na terenie Czarnogóry) i powierzchowne traktowanie opisywanej rzeczywistości kulturowej, uzasadniła, że przenikanie literatury i dziennikarstwa pozwoliło Stasiukowi wykreować antycywilizacyjny i antyeuropejski obraz Bałkanów, a poprzez petryfikację opozycji - słowiańskie-bałkańskie-zachodnioeuropejskie - reprodukcję utrwalonych wyobrażeń. Autor wykorzystując swoistą modę na Bałkany skorygował stygmatyzowaną wcześniej wizję i ich obraz nieco złagodził w Dzienniku pisanym później z 2010 roku dokonując dyskretnej autokorekty w opisie. Choć od stereotypu nie odstąpił, gdy w oparciu o powierzchowną wiedzę i obserwację, czerpiąc z obrazów innych, mnożył ambiwalentne określenia regionu, gdzie Bałkany jawią się jako „kraina śmierci”, „ojczyzna wampirów”, a stanowią je „kraje z wyrazistą osobowością” (s. 262). Tym samym dla Stasiuka sam bałkanizm stał się akcentem obciążającym, który uwypukla opozycję „gorszej Europy” wobec Zachodu.

Marta Chaszczewicz-Rydel poddała też analizie prozę Dominiki Ćosić z jej perspektywą narracyjną tzw. podwójnego kodowania polegającego na łączeniu spojrzenia z perspektywy obcego ze spojrzeniem wywodzącego się z tego obszaru (auto- $\mathrm{i}$ heteroobrazy). Wykorzystała także wizje literackie stworzone w ramach nurtu literatury feministycznej. Do tego posłużyły jej genderowe opowiadania Ingi Iwasiów, Smaki 
$i$ dotyki, koncentrujące się na narracji o „gorszych kobietach z gorszej Europy” (s. 264). Dla tej bowiem autorki, której inspiracje dostrzegła badaczka w prozie Dubravki Ugresić i Vedrany Rudan, Bałkany stanowią połączenie z wojną i negatywnymi zjawiskami społecznymi, takimi jak patriarchalizm, czy sytuacja społeczna kobiet w czasie wojny. Zestawienie bałkańskiej kobiety ze światem bałkańskich mężczyzn wykreowało przygnębiający obraz kobiety, która stała się ofiarą wielokrotnej dominacji, a same Bałkany ukazane zostały w kontekście patriarchalnym, neokolonialnym i przestępczym. W sytuacji, gdy nobilitacja bałkańskiej kobiety mogłaby się dokonać przez romans z cudzoziemcem, mężczyzna z Zachodu, jako wcielenie elegancji, spokoju, ukształtowany został w kontraście do męskiego typu bałkańczyka. Standaryzacji w prozie Iwasiów podległa także przestrzeń miejska z jej kurzem, pyłem, brudem, wrażeniem ciasnoty i klaustrofobii, a sam przymiotnik „bałkański” stał się nośnikiem istotnych treści i wartości afektywnych, zazwyczaj negatywnych. Pisarka posłużyła się starymi określeniami Bałkanów, ale sama też stworzyła nowe, takie jak: „,bałkański kociołek”, „bałkański folk”, „,bałkański kurort”, „,bałkańska prowincja”, „bałkańskie pokrewieństwo”, „bałkańskie życie” (s. 276), przy czym nagromadzone stereotypy o bałkańskim patriarchalizmie służyć maiły zdemaskowaniu uniwersalnych konsekwencji płci. M. Chaszczewicz-Rydel omawiając prozę tej autorki doszła do wniosku, że zbiór jej prozy, mimo swych zalet literackich, stanowi powielenie stereotypów o Bałkanach i te stereotypy jedynie utrwala.

Kolejną pisarką, której twórczość została poddana analizie pod kątem imagologii Bałkanów stanowi proza Olgi Tokarczuk, Bieguni. Zbudowany obraz z opisem wyspy Vis, stał się dla pisarki prezentacją pustkowia o cechach infernum, skansenu i oddalenia od Zachodu, a tworzący ten świat mężczyźni reprezentantami typu bałkańskiego maskulinizmu. Opis świata Bałkanów wyłonił zastygły porządek, reprezentując „,gorszą Europę” „innej prędkości” (s. 291).

Zasygnalizowana tu pokrótce problematyka monografii Marty ChaszczewiczRydel, choć ograniczona tylko do byłej Jugosławii, pozwala na skonfrontowanie postrzegania regionu i weryfikację narosłych wokół Bałkanów stereotypów. Badaczka dokonała nie tylko wnikliwej analizy twórczości literackiej o tej przestrzeni, ale także w zamieszczonych przypisach zestawiła omawiane przykłady ze schematem poznawczym stworzonym przez Europę Zachodnią wskazując na swoisty postkolonialny resentyment wobec Bałkanów. Odnosząc się do faktów dotyczących Serbii, jak również do badań dyskursów feministycznych oraz źródeł negatywnego obrazu Bałkanów, wskazała, iż proza podtrzymuje dwubiegunowy i uproszczony sposób myślenia o tej części kontynentu, poprzez który dokonuje się wtórna orientalizacja przestrzeni i sposobu myślenia o niej. Jak zauważyła, przytaczając opinię Dariusza Skórczewskiego w odniesieniu do prozy Stasiuka, popularność takiej wizji wśród czytelników zachodnich może wynikać z faktu fundowania tej publiczności obrazu ,gorszej Europy” jako obrazu zgodnego z jej oczekiwaniami. 
